\title{
Blockchain Technologies and Smart Contracts: New Technological Methods to Regulate Transactions and Trade Operations
}

\author{
Tatyana Vladimirovna Deeva ${ }^{1}$, Galina Nikiporets-Takigawa ${ }^{2}$, Tatyana Nikolaevna Lustina ${ }^{3}$, \\ Elena Nikolaevna Podsevalova ${ }^{3}$, Elvira Nikolaevna Didenko ${ }^{4}$ \\ ${ }^{1}$ Market Economy Institute of the Russian Academy of Sciences (MEI RAS), Russia \\ ${ }^{2}$ Russian State Social University, Russia \\ ${ }^{3}$ Russian State University of Tourism and Service, Russia \\ ${ }^{4}$ Financial University under the Government of the Russian Federation, Russia
}

\begin{abstract}
The article presents a study of blockchain technology from the point of view of legal regulation prospects, as well as the possibility of using one of the areas of this technology application - smart contracts as an analog of contracts in civil circulation, taking into account the legal field of the Russian Federation. The purpose of the article is to form recommendations on the possible development of areas of Russian regulation of blockchain technology and the use of smart contracts. The article analyzes international approaches to the regulation of digital technologies, practices, and features of their application, as well as the proposed legal norms of the Russian bill on the use of digital technologies in civil turnover. The article shows the huge possibilities of using blockchain technology, as well as the possible risks of its use in certain areas. The article examines the opinions of scholars on the prospects for the development of legal regulation of blockchain technology in general, and smart contracts, in particular, in the Russian Federation. It is noted that since regulatory regulation and judicial practice on smart contracts in the Russian Federation has not yet developed, at the moment, participants in smart contracts cannot exercise the right to protection. It is indicated that the regulation of smart contracts does not require a separate regulatory design, so with the existing technical innovations, they are subject to classical contract law, which has formed a complete theory of transactions, which can be applied to cases of using smart contracts. In connection with this conclusion, the authors give recommendations on making amendments to the current civil and emerging digital legislation.
\end{abstract}

Key words: Blockchain technology, smart contract, digital legislation, judicial practice, legal regulation.

\section{INTRODUCTION}

Currently, various digital technologies are rapidly spreading in the economy, and one of the most famous of which is the blockchain technology.

The first mention of blockchain technology can be found in a work written by a person or group of people under the pseudonym "Satoshi Nakamoto," - "Bitcoin: a peer-to-peer electronic monetary system" [1]. The scope of application of this technology has significantly expanded in recent years due to the emergence of digital payment instruments based on it, as well as tools for concluding and fulfilling contractual obligations, the so-called smart contracts [2-5].

For example, smart contract technology can be used in the activities of financial organizations [6]:

- in the performance of interbank settlements. In particular, blockchain technology can replace an intermediary entity (for example, SWIFT), from which organizations need to open a correspondent account to conduct operations;

- optimization of the processes of issuing loans secured by property, in particular when maintaining registers of collateral rights based on blockchain;

- optimization of the process of issuing letters of credit. In this case, the blockchain reduces the risk of distrust between the parties. Such an operation has already been carried out in the Russian Federation: in 2016, Alfa-Bank PJSC and S7 Airlines conducted a letter of credit transaction via blockchain using smart contracts for the first time in Russian practice [7].

In the insurance industry: the German insurance company Allianz uses smart contracts to automate insurance payments in the event of natural disasters [8].

There are examples of using smart contracts in other sectors of the economy. For example, Gazpromneft-Aero, the operator of Gazprom Neft's jet fuel business, S7 Airlines, and 
Alfa-Bank have tested digital smart contracts based on blockchain technology. Due to the smart contract, the airline has the opportunity to instantly pay for fuel directly when refueling aircraft: without prepayment, bank guarantees, and financial risks for participants in the transaction [9].

In this regard, regulators in different countries are forced to take measures to legally regulate the use of this form of transaction. Such measures can be quite different: from simply informing the subjects of possible risks to the adoption of detailed laws that establish the sequence of actions of the parties, their rights and obligations of the subjects, as well as up to ignoring this form, not recognizing the participants' right to judicial protection. The Russian legal regulation mechanism is still far from being formed, and the existing draft law on the circulation of digital financial assets containing the concept of a smart contract has not yet been approved [10, 11].

The need to regulate the use of smart contracts in the financial market is also confirmed by the use of this tool when performing settlement operations for the purchase of prohibited goods and services. The European Union's police service also warns of the existence of such risks. In its report "Internet Organized Threat Assessment 2018," it indicated that criminals will use smart contracts in the coming years to organize terrorist attacks, fraud, and bribery [12].

Many scholars are interested in blockchain technology in general and smart contracts in particular. In the works of A.I. Savelyev [6, 13], A.Yu. Churilov [14], I.A. Rumyantsev [15], and A.A. Emelyanov [16], presented in the public domain, mainly technical principles of the functioning of the blockchain are revealed, and prospects for its application in the economy are shown. At the same time, there are still relatively few works analyzing the legal aspects of the use of smart contracts in civil circulation. The turnover of digital rights and the use of digital technologies in it has several significant features, which makes it necessary to study the prospects for special regulation, primarily in the Civil Code of the Russian Federation. Thus, the analysis of possible options for the development of regulation of blockchain technology in the general and smart contracts as one of the possibilities of using this technology, in particular, is very relevant and can contribute to the justification of new scientific ideas.

Research hypothesis. In the absence of statutory regulation or any judicial practice, it seems that a party to a smart contract that has fulfilled its obligations in good faith but has not received adequate counter-satisfaction from the other party is not entitled to judicial protection.

\section{METHODS}

The research was performed using a dialectical method of cognition of reality, which allowed studying the essence of blockchain technology in the dynamics of its development.
The statistical method showed that blockchain technology is increasingly used in various sectors of the economy and allowed justifying the need for high-quality legal regulation. The method of transition from a general concept to a private one allowed distinguishing such a sphere of application of blockchain technology as smart contracts. Using the comparative legal method, the international experience of regulating the use of blockchain technology was summarized and the possibility of its use in the Russian legal field was analyzed. The formal legal method allowed identifying terminology that can be used in the regulatory design of emerging digital legislation. To prove the research hypothesis, the currently relevant sources of information were selected - Internet sites containing statistical data and analytics, legal practice selections, draft laws with comments for the past and current years.

\section{RESULTS}

The blockchain is a database distributed among all devices included in the Blockchain Network, using which users transmit information $[14,17,18]$. Information about transactions in the blockchain system represents the amount of data combined in a kind of links, which, in turn, are combined in chronological order in a chain of blocks, in which each previous block confirms the validity of the subsequent one by including information about previous transactions in the form of a special cryptographic key in the header of each subsequent block of transactions. Thus, each block is identified using a cryptographic key, a hash, which is generated using the SHA2562 cryptographic algorithm [19]. At the same time, each of the network participants stores at least part of the entire database, which ensures its stability against illegal actions by both third parties and the participants themselves.

In connection with the popularization of blockchain technology in the world, there are two generations of development of this technology - blockchain 1.0, which symbolizes the only cryptocurrency, and blockchain 2.0, which includes other methods of application, such as "smart contracts", "smart property", and distributed storage of information [20].

State regulation of digital technologies in the Russian Federation, including blockchain technologies, is currently in the initial stage. In the current decade, large-scale documents have been adopted.

The Strategy for the Development of the Information Society in the Russian Federation for 2017-2030, approved by presidential decree No. 203 of May 9, 2017 [21], as well as in 2017. The Government of the Russian Federation approved the program "Digital Economy of the Russian Federation" [22]. The functional structure of the system for managing the implementation of the national program, the procedure for 
developing, monitoring and controlling the implementation of federal projects included in its composition are disclosed in the Regulation on the system for managing the implementation of the national program "Digital Economy of the Russian Federation" [23]. The main goals of the national program are complex and interrelated and are reflected in six areas of activity of the Government of the Russian Federation: 1) statutory regulation of the digital environment; 2) formation of personnel for the digital economy; 3 ) creation of information infrastructure; 4) ensuring information security; 5) application of digital technologies; 6) digital public administration. A distributed registry system (blockchain) has been singled out among the technologies, and a roadmap is currently being developed - a strategic document for the implementation and development of blockchain in Russia. The potential effect of the introduction of blockchain technology is projected to exceed 1.5 trillion rubles by 2024 [24]. To implement the development strategy of the information society and the Digital Economy of the Russian Federation program, draft federal laws have been developed and are undergoing approval and adoption: "On digital financial assets", "On the system of distributed national mining," "On alternative ways to attract investment (crowdfunding)", "On amendments to parts one, two and four of the Civil Code of the Russian Federation".

The draft law "On Amendments to Parts One, Two, and Four of the Civil Code of the Russian Federation" defines the terms "digital money" and "digital rights", provides for their judicial protection, uses the concept of a decentralized information system, which includes blockchain technologies. At the moment, such important bills have not yet been adopted. The Civil Code of the Russian Federation currently enshrines the concept of "digital rights". This indicates the need for statutory regulation of digital assets and rights, recognition of blockchain technology and cryptocurrency [25], and, therefore, smart contracts.

Analysis of international experience shows that China is the undisputed leader in the development and use of blockchain technologies at the present stage. State regulation of blockchain technologies can be divided into two types: a) state regulation of blockchain technologies is carried out per separate rules of law, special legislative and regulatory acts for blockchain technologies are developed at all levels of government; b) the regulation of blockchain technologies is "embedded" in existing regulations, only specific problems are separately regulated [25]. The first way is chosen by China: state regulation of blockchain technologies is implemented at the Federal level - the government and ministries (macro-level) and at the regional level - the government bodies of the provinces of China. The State Council of China adopted the national plan for the information development of China (13th five-year plan), which focuses on blockchain technology and the blockchain industry. The Ministry of Industry and Information Technology has released a White Paper on the blockchain industry in China (2018 White Paper on China's Blockchain Industry), which contains an in-depth analysis of the current state of China's blockchain industry, predicts its development trends and provides standards for the use of blockchain technologies [26]. Provincial regional government bodies have adopted documents related to the development of blockchain technologies. Zhejiang, Jiangsu, Guizhou, Fujian, Guangdong, Jiangxi, Shandong, Inner Mongolia, and Chongqing provinces issued blockchain instructions, some provinces included the development of blockchain technologies as one of the items in the 13th five-year strategic development plan of the region. Currently, the governments of the provinces of Shenzhen, Hangzhou, Guangzhou, Guiyang, and Ganzhou are creating industrial parks — zones for the development of blockchain technologies, which are provided with special support programs. The United States took the second model as a basis - state regulation of blockchain technologies is carried out by the federal government, federal agencies (macro-level), state government bodies (regional level). The federal government at the time of the study has not yet adopted uniform regulations and documents regulating the development of blockchain technologies in the United States. Government regulation is implemented at the level of US federal agencies within their competencies. At the same time, US state authorities are adopting local regulations and rules for the use of blockchain technologies. According to the economic report of the US Congress in 2018, state regulation of blockchain technologies is planned to be "embedded" in the regulatory system of securities, money circulation, taxation, etc. [27].

Currently, the use of smart contracts in the financial market is allowed in 45 countries [28]. However, there are two approaches to their regulation:

- adoption of new regulatory legal acts, including laws on amendments to existing legislation (this approach, for example, is typical for Mexico, Belarus, Australia, Estonia);

- issuance by regulators of explanations on the application of current legislation when using smart contracts in the financial market (for example, in Singapore, Germany, the United States) [28].

At the same time, the position of regulators in this matter is practically the same: a smart contract is a form of the transaction since it is a sequence of programmed computer functions that allow the most supported computer code to perform actions at a given time and/or based on the occurrence or non-occurrence of certain actions or events [28].

The Draft Law on Amendments to the Civil Code of the Russian Federation equates to a simple written form of the 
transaction "the expression by a person of his/her will using electronic or other similar technical means" [29]. As a condition of compliance with the written form, in this case, will be the circumstances in which the will of the parties is expressed through the use of technical means (https://urfac.ru/?p=1976 - _ftn11). The legislator classifies these actions as legally relevant messages (following Article 165.1 of the Civil Code of the Russian Federation).

\section{DISCUSSION}

From a technical point of view, a smart contract is defined as a computer algorithm designed to conclude and maintain commercial contracts in the blockchain technology [30, 31, 32]. In other words, it is a decentralized system that provides the parties involved in the negotiations with a secure transaction, verification, and compliance with all the conditions, eliminating the need to hire intermediaries. The process takes place in digital form, and programming and cryptography tools are used to describe the contract and its result [9]. In the doctrine of civil law, this type of obligation is under development, and the new version of the Civil Code of the Russian Federation does not contain its legal definition. However, it should be noted that in 2018, attempts were made to consolidate the concept of "smart contract" by the Ministry of Finance of Russia together with the Bank of Russia [33]. Article 2 of the Draft Federal Law "On Digital Financial Assets" defines a "smart contract" as an agreement in electronic form, the fulfillment of rights and obligations of which is carried out by automatically making digital transactions in a distributed register of digital transactions in the sequence strictly defined by such an agreement and upon occurrence certain circumstances. This definition allows considering a smart contract as a type of civil contract, which creates a certain complexity for the perception of the concept by domestic law.

The Russian Federation has not yet developed a judicial practice in relation to smart contracts. The main number of disputes in the field of application of blockchain technology in the financial market is devoted to the use of cryptocurrency. Currently, there are more than 134 disputes in this area [28], of which almost $40 \%$ are civil disputes related to the recognition of an obligation to pay for a particular property by transferring cryptocurrency to a counterparty. In this matter, the court practice is not in favor of persons who prove the fact of payment under purchase and sale agreements. Thus, the decision of the Ryazhsky Court of the Ryazan region in case No. 2-160/2017 stated that "the presence of cryptocurrencies outside the legal field does not allow the plaintiff to implement legal mechanisms for imposing liability on the defendant in the form of paying the latter a penalty, compensation for moral damage and a fine, provided for by the Law of the Russian Federation dated February 07, 1992 No. 2300-1 "Concerning the Protection of Consumers'
Rights" [33]. This situation is due to the lack of legislative regulation of the use of cryptocurrency, and it can be assumed that the position of the courts will be similar in the event of disputes concerning smart contracts.

Let us look at the main aspects of a smart contract as an agreement. A smart contract provides automated execution, meaning that a smart contract will not only be concluded when wills are agreed but by its nature, it will only be concluded if users who have reached an agreement can simultaneously execute the smart contract. In accordance with this, it can be concluded that today, using smart contracts, only the turnover of those objects is possible, within which the computer can "assess" the availability of their execution. The execution doesn't need to take place within the framework of the blockchain, it is important that the program can verify the execution (for example, the transfer of things and setting the fact of arrival at the place of execution using tags). Thus, the author concludes that everything that a computer can "accept" as execution can be the subject of a smart contract [15]. At the same time, the majority of approaches developed in relation to contract law concerning a smart contract are saved and applied. Here, the opinion of A.I. Savelyev, who points out that most concepts of contract law, such as obligation, non-performance, or improper performance, are not applicable to smart contracts. He writes: "Since one of the key elements of an obligation is its orientation to the future and subsequent volitional actions (inaction) of the obligated person to fulfill it, in a situation where the relevant conditions are fulfilled by the computer itself, the very concept of "obligation" loses its meaning. Computer operations are important in a "smart" contract, but not the behavior of the debtor, which is the core of the concept of "obligation" [13]. A.I. Savelyev also claims that "any execution made by software code will be considered "proper", and therefore this concept itself loses its meaning since there can be no improper execution within the framework of a "smart" contract" [13]. This approach seems wrong. The following statement of I.A. Rumyantsev is true: "A smart contract is only a way to exercise civil rights, and civil rights, like the law in general, live their own lives and represent the type and measure of proper behavior of people. A smart contract is a way to exercise civil rights. If the economic goal that the person set when entering into a smart contract was not achieved due to, for example, intentional actions of the counterparty, then such a person should have the right to protect civil rights" [15]. With this approach to the regulation of smart contracts, there are quite promising and interesting opportunities for introducing this form of registration of contractual relations into legal practice.

\section{CONCLUSION}

The research conducted in this article allowed drawing several conclusions. The legal regulation of blockchain 
technology in the Russian Federation has not been formed at the moment. Existing digital law bills do not take into account all the properties and specifics of the blockchain and digital assets produced on its platform. There are several significant features in the sphere of circulation of digital financial acts as objects of civil rights, and this necessitates special regulation, primarily in the Civil Code of the Russian Federation, the rules of which have priority over the rules of civil law contained in other federal laws. At the moment, it is proposed to consider a smart contract as a type of contract with a special procedure for its conclusion, which makes it possible to apply it in practice, using the existing mechanisms of contractual regulation. However, due to the lack of legal regulation, judicial protection of the rights of the parties to a smart contract is not guaranteed by law. Thus, the hypothesis of this study is proved. In terms of continuing research on the use of blockchain and smart contracts, it is most interesting to analyze the possibilities of using this technology and the way to exercise civil rights in the political sphere, public administration, as well as individual sectors of the economy.

\section{REFERENCES}

1. S. Nakamoto. Bitcoin: A Peer-to-Peer Electronic Cash System. Availaable at: https://bitcoin.org/bitcoin.pdf

2. D.A. Musabirova, R.N. Hamitov . The Category of 'Unfairness' in the Contract System Legislation in Russia and the USA: Some Interpretation Issues, Journal of Advanced Research in Law and Economics, Vol. 7, No. 7, pp. 1781-1788, 2017.

3. O.N. Bykova, A.P. Garnov, M.V. Milonova, E.V. Trokhova, L.V. Progunova, A.A. Prikladova, O.S. Ivanov. Methods for Combating Unfair Competition in the Intellectual Property Market in Russia and Abroad, Journal of Advanced Research in Law and Economics, Vol. 10, No 2, pp. 477-487, 2020. https://doi.org/10.14505//jarle.v10.2(40).07

4. E.M. Lubkova, T.F. Gorbachev, A.E. Shilova, T.F. Gorbachev, G.S. Ermolaeva. New Reality of the Banking Market: E-Banking and M-Banking (The Russia Case Study), Journal of Advanced Research in Law and Economics, Vol. 10, No. 2, pp. 574-582, 2020. https://doi.org/10.14505//jarle.v10.2(40).18

5. T.V. Pogodina, ТюДю Udaltsova, A.V. Filushina. Paradigm Shift in Technological Development of Socio-Economic System in the Context of Digital Transformation. Journal of Advanced Research in Law and Economics, Vol. 10, No 2, pp. 653-662, 2020.

6. A.I. Savelyev. Nekotorye pravovye aspekty ispolzovaniya smart-kontraktov i blokchein-tekhnologii po rossiiskomu pravu [Some legal aspects of the use of smart contracts and blockchain technologies in Russian law], Zakon, Vol. 5, p. 45, 2017.

7. Alfa-Bank and S7 Airlines for the first time in Russia conducted a transaction using the blockchain. December 21, 2016. Available at: https://alfabank.ru/press/news/2016/12/21/37627.html

8. A.B. Dzaurova, A.D. Sitnikova. "Smart-kontrakty" v mezhdunarodnom chastnom prave [Smart Contracts in Private International Law], Alleya nauki, Vol. 1, p. 634, 2019.

9. A.V. Samoylova, O.E. Kozlova. Osobennosti smart-kontraktov $\mathbf{v}$ RF (na osnove primera kontrakta, zaklyuchennogo mezhdu S7 Airlines i "GazpromneftAero") [Features of smart contracts in the Russian Federation (based on an example of a contract concluded between S7 Airlines and GazpromneftAero)], KiberYurist, Vol. 12, No 1, p. 81-88, 2019.

10. S. Zenin, D. Kuteynikov, O. Izhaev, I. Yapryntsev. Applying Technologies of Distributed Registries and Blockchains in Popular Voting and Lawmaking: Key Methods and Main Problems. Amazonia Investiga, Vol. 8, No. 20, pp. 330-339, 2019.

11. E.A. Kirillova., V.V. Bogdan, I.B. Lagutin, E.D. Gorevoy. Estado legal de los contratos inteligentes: características, papel, significado, Juridicas, Vol. 15, No 1, pp. 285-300, 2019. https://doi.org/10.17981/juridcuc.15.1.2019.11

12. Internet Organized Threat Assessment. Europol, 2018. Available at:

https://www.europol.europa.eu/internet-organised-crime -threat-assessment-2018

13. A.I. Savelyev. Dogovornoe pravo 2.0: "umnye" kontrakty kak nachalo kontsa klassicheskogo dogovornogo prava [Contract Law 2.0: Smart Contracts as the Beginning of the End of Classic Contract Law], Zakon, Vol. 12, p. 57, 2017.

14. A.Yu. Churilov. Ispolzovanie tekhnologii blokchein: platezhnaya sistema, "umnye" kontrakty, prinyatie kollegialnykh reshenii, khranenie informatsii Pravo v sfere Interneta: Sbornik statei [Use of blockchain technology: payment system, smart contracts, collegial decision-making, information storage. Law in the Internet sphere: Collection of articles]. Statut, Moscow, p. 145, 2018.

15. I.A. Rumyantsev. Blokchein i pravo Pravo v sfere Interneta: Sbornik statei [Blockchain and Law Internet Law: A Collection of Articles] Statut, Moscow, p. 157, 2018.

16. A.A. Emelyanov, E.Yu. Avksentieva, S.Yu. Avksentiev, N.N. Zhukov. Applying Neurointerface for Provision of Information Security, International Journal of Advanced Trends in Computer Science and Engineering, Vol. 8, No 6, pp. 3277-3281, 2019. https://doi.org/10.30534/ijatcse/2019/97862019

17. YU. Fedorova, A.A. Urunov, I.B. Rodina, V.A. Ostapenko. Financing and quality of housing construction: introduction of information systems as a regulatory tool, Revista Inclusiones, Vol. 7, No. Special, pp. 328-339, 2020. 
Tatyana Vladimirovna Deeva et al., International Journal of Emerging Trends in Engineering Research, 8(7), July 2020, 3659 - 3664

18. V.Ya. Tsvetkov, V.M. Feoktistova, A.M. Minitaeva, Y.P. Kozhaev, L.P. Belyu. Metamodelling in the information field, Amazonia Investiga, Vol. 9, No 25, 395-402, 2020.

19. A.M. Antonopoulos. Mastering Bitcoin. O'Reily Media, p. 170, 2015.

20. Blockchain and Beyond. Version 1.0. Cellabz, November 2015. Available at:

https://blockchainfrance.files.wordpress.com/2015/12/ce llabz-blockchain-beyond.pdf

21. Decree of the President of the Russian Federation of May 9, 2017 No 203 "On the Strategy for the Development of the Information Society in the Russian Federation for 2017 - 2030". Available at: http://www.kremlin.ru/acts/bank/41919

22. "Passport of the national project "The National Program "Digital Economy of the Russian Federation" (approved by the Presidium of the Presidential Council for Strategic Development and National Projects, Minutes dated 04.06.2019 No 7). Available at:

https://legalacts.ru/doc/pasport-natsionalnogo-proekta-n atsionalnaja-programma-tsifrovaja-ekonomika-rossiisko i-federatsii/

23. Decree of the Government of the Russian Federation of March 2, 2019 No 234 (as amended on December 7, 2019) "On the system for managing the implementation of the national program "Digital Economy of the Russian Federation" (together with the "Regulation on the system for managing the implementation of the national program "Digital Economy of the Russian Federation"). Available

at:

http://publication.pravo.gov.ru/Document/View/000120 1903070015

24. E. Kazachenko, D. Komakhidze, M. Sheina. The future of digital technologies in Russia: work plans for 5 years found their first contours. Budushchee Rossii, Natsional'nye proekty [The Future of Russia, National Projects], May 24, 2019. Available at:

https://futurerussia.gov.ru/nacionalnye-proekty/422373

25. N.A. Kovaleva. Praktika gosudarstvennogo regulirovaniya primeneniya blokchein-tekhnologii i ee sovershenstvovanie na osnove zarubezhnogo opyta [The practice of state regulation of the use of blockchain technologies and its improvement based on foreign experience], Ekonomika. Nalogi. Pravo, Vol. 12, No 4, pp. 87-93, 2019.

https://doi.org/10.26794/1999-849X-2019-12-4-87-93

26. White Paper on the Development of China's Blockchain Industry, 2018. Available at:

https://cryptocurrencytracker.info/et/crypto-news/10379 /chinas-it-ministry-2017-saw-peak-investment-in-domes tic-blockchain-industry

27. The 2018 Joint Economic Report, Joint Economic Committee of the US Congress. Available at: https://www.congress.gov/115/crpt/hrpt596/CRPT-115h rpt596.pdf
28. V.K. Shaidullina. Smart contracts in the financial market: research results. YurFak, May 8, 2019. Available at: https://urfac.ru/?p=1976

29. Draft Federal Law No 424632-7 "On Amendments to Parts One, Two and Four of the Civil Code of the Russian Federation". Available at: https://sozd.duma.gov.ru/bill/424632-7

30. Draft Federal Law No 419059-7 "On Digital Financial Assets". Available at: https://sozd.duma.gov.ru/bill/419059-7

31. M.M. Nimatulaev, K.K. Sirbiladze, O.N. Tsvetkova, L.I. Ivanova, E.E. Konovalova. Improvement of information technologies in the hotel business, Revista Turismo, Vol. 9, No 1, pp. 1-9, 2020.

32. M.O. Chepizhko. Smart-revolyutsiya: "Gazpromneft-Aero" vnedryaet smart-kontrakty na osnove tekhnologii blokchein [Smart revolution: Gazpromneft-Aero implements smart contracts based on blockchain technology], Sibirskaya neft, Vol. 8/155, p. 40, 2018.

33. Analysis of judicial practice on cryptocurrencies in Russia. RTM Group. Available at: www.abiss.ru/upload/iblock/f3b/2017-5-I_Kriptovaluti_ SudebnayaPraktika.pdf 